Jpn. J. Med. Mycol.

Vol. 44, 87-92, 2003

ISSN $0916-4804$

総説

\title{
カンジダ属の抗真菌薬耐性について ーアゾール耐性を中心に
}

\author{
掛屋弘宮㟝泰可宮㟝 義 継 \\ 河野茂 \\ 長崎大学大学院医歯薬学総合研究科 \\ 新興感染症病態制御学系専攻 \\ 感染分子病態学講座 \\ 病態生理制御学分野
}

Key words: アゾール系抗真菌薬 (azole antifungal agents), アゾール耐性機序 (mechanism of azole resistance), $14 \alpha$-demethylase, 薬剤排出ポンプ (efflux pump), $\Delta 5,6$ desaturase

\section{はじめに}

アゾール系抗真菌薬は, 1958 年欧米で上市されて以来, その高い抗真菌活性と優れた安全性を有する抗真菌薬で ある. 1980 年代以降，欧米で AIDS が蔓延したことや医 療技術の進歩により免疫抑制患者が増加したことに起因 する日和見感染症の治療や予防に頻用されるようになつ ている. その結果, 1980 年代後半からアゾール耐性のカ ンジダ属を誘導することとなつた.アゾール耐性カンジ ダ属における現在のもう一つの問題点は, アゾール系抗 真菌薬に自然耐性のカンジダ属, すなわち Candida glabrata やC. krusei などの分離頻度が高くなっていることであ る.これらの問題により, 臨床において初期治療が不成 功に終わり, 抗真菌薬の大量投与や変更を余儀なくされ る場合がある. 近年は, AIDS に対しては HAART 療法 が導入されたことにより, 耐性カンジダの分離頻度は低 下していると報告されている1,2) が，その機序の解明や 対策はまだ十分とはいえない.

\section{アゾール耐性機序}

カンジダの耐性機序の研究は 1990 年代に入り, 盛ん に行われるようになり，現在まで主に 4 つの耐性機序が 明らかになっている。

1) $E R G 11$ 遺伝子の過剩発現による相対的な標的酵素 の増加

アゾール系抗真菌薬の標的酵素である $14 \alpha$-demethylase をコードする $E R G 11$ 遺伝子の過㮃発現の結果とし て, 標的酵素の量が増加して起こる耐性機序である.

別刷請求先 : 掛屋 弘

T852-8501 長崎市坂本 1 丁目 7-1

長崎大学大学院医歯薬学総合研究科
mRNA の発現レベルでみるとERG11 遺伝子の過㮃発現 は, 2 時間以内の FLCZ の暴露によっても引き起こされ ることが分かっている. しかし, その過剩発現は薬剤感 受性を 3 から 5 倍程度低下させるが, 高度耐性を引き起 こす原因とはならないと報告されている3).

\section{2 ）ERG11 遺伝子の point mutation}

$E R G 11$ 遺伝子に point mutation が起こり, その産物 である $14 \alpha$-demethylase のアミノ酸の極性が変化し, さ らに立体構造の変化をもたらすことでアゾール系抗真菌 薬との親和性（結合性）が低下することによる耐性機序 である.すでにC. albicans において多くのアミノ酸変異 が報告されているが，アミノ酸変異の中でも 132 番目の チロシン（Y）がヒスチジン（H）に変異した $\mathrm{Y} 132 \mathrm{H}$ および heme binding domain とよばれる470番目のシ スチン（C470）周囲のアミノ酸変異が, アゾール耐性株 に報告されている4). $14 \alpha$-demethylase の推定されてい る立体構造をみると（Fig. 1), Y $132 \mathrm{H}$ 周辺はアゾール 系抗真菌薬との結合部を形成するアミノ酸の一つと考え られている.また, C470周辺はへム鉄と結合する活性中 心の部位にあたり，その周囲のアミノ酸変異 $(\mathrm{S} 405 \mathrm{~F}$, G464S，R467K）も，アゾールとの親和性（結合性）を 低下させると考えられている5).

私達は 1993 年長期 ketoconazole（KCZ）が投与され た患者より分離された高度アゾール耐性 Darlington 株 (MIC $256 \mu \mathrm{g} / \mathrm{ml}$ ) の而性機構についての検討を行った. その耐性機序としてポンプ遺伝子やエルゴステロール合 成経路における変化は, 耐性機序に関連しないと報告さ れているが6,7)，未だ明らかでない点も多い4).

私達は $E R G 11$ 遺伝子の変異に注目した. Darlington 株の $E R G 11$ 遺伝子には感受性株の遺伝子配列8) と比較 すると，両対立遺伝子ともに $\mathrm{Y} 132 \mathrm{H}$ と $\mathrm{I} 471 \mathrm{~T}$ （471番目 


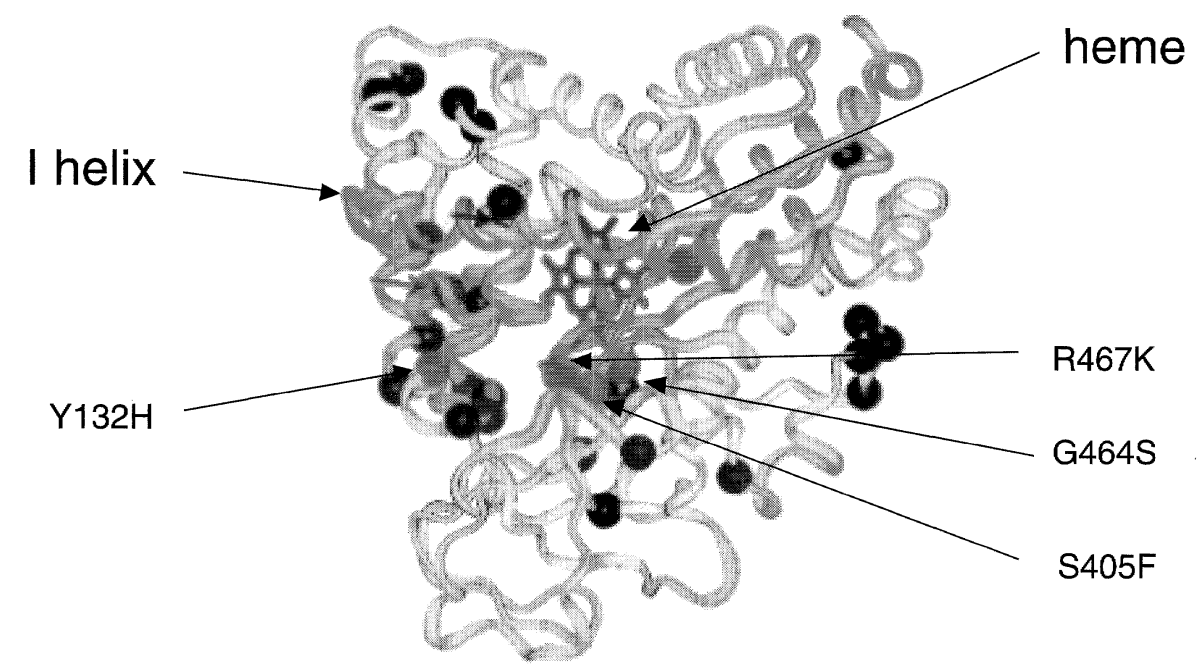

: Mutations which are important for azole resistance

Fig. 1. Three - dimensional model of C. albicans $14 \alpha$-demethylase structure ${ }^{4)}$.

The mutations are marked by spheres. The substitutions found in both azole-sensitive andresistant strains are represented by black spheres, and the substitutions demonstrated to be important for azole affinity are shown in gray.

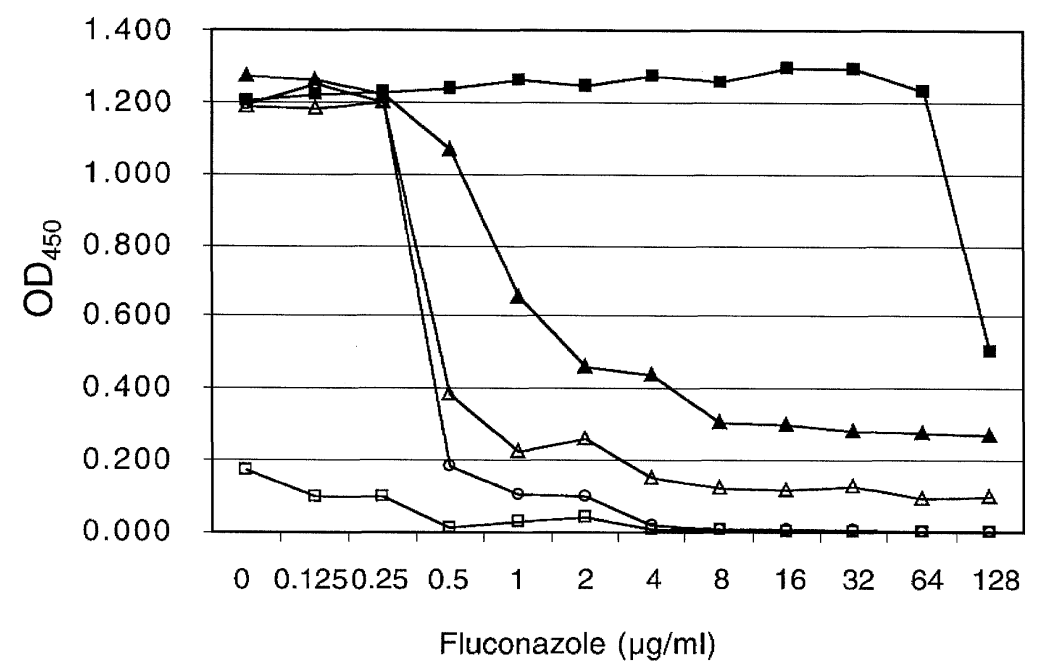

Fig. 2. Fluconazole growth inhibition in C. albicans at day 4.

Data are for C. albicans isolates CAI4 (open squares), CAF2-1 (open circles), SC5314 (open triangles), Darlington (filled squares), and transformant 12 (filled triangles). OD 450 , optical density at $450 \mathrm{~nm}^{9}$ ).

のイソロイシン（I）からスレオニンへ（T）の変異） の二つのアミノ酸変異をもたらす遺伝子変異があり, そ の変異に関してホモ接合体であることが明らかとなった. 一方, 感受性株 (CAI4 株) のERG11 対立遺伝子の一つ は，野生株と同様で，もう一力には二つのアミノ酸変異 (D116E，K128T）があったが，両アミノ酸変異とも感 受性株に報告されている変異であった ${ }^{4)}$. そこで, 私達 はこの感受性株の一つの ERG11 遺伝子（C-ERG11）を Darlington 株由来の ERG11 (D-ERG11) と置換した形 質転換株（ヘテロ接合体：transformant 12）を作成し， それらの fluconazole（FLCZ）に対する薬剤感受性を検 討した. その結果 (Fig. 2), 各 well の検濁度を比較する
と, Darlington 株は FLCZ に高度耐性であり, CAI4 株 やその親株である SC5314 および CAF2-1 株（MIC 0.5 $\mu \mathrm{g} / \mathrm{m} l)$ は感受性であることを示していた。一つの Darlington 株由来の ERG11 遺伝子を有する形質転換株 の薬剤感受性は, Darlington 株には及ばないものの感受 性株より耐性に変化した.この変化は遺伝子置換による

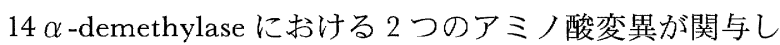
ていることを示唆していた.

そこで, どちらのアミノ酸変異が主要な耐性化機序に 関わっているかを明らかにするために，それぞれの変異 を有する $E R G 11$ 遺伝子を過剰発現させ, 薬剤感受性を 検討した. 感受性株由来の ERG11 遺伝子や Darlington 
Deletion construct

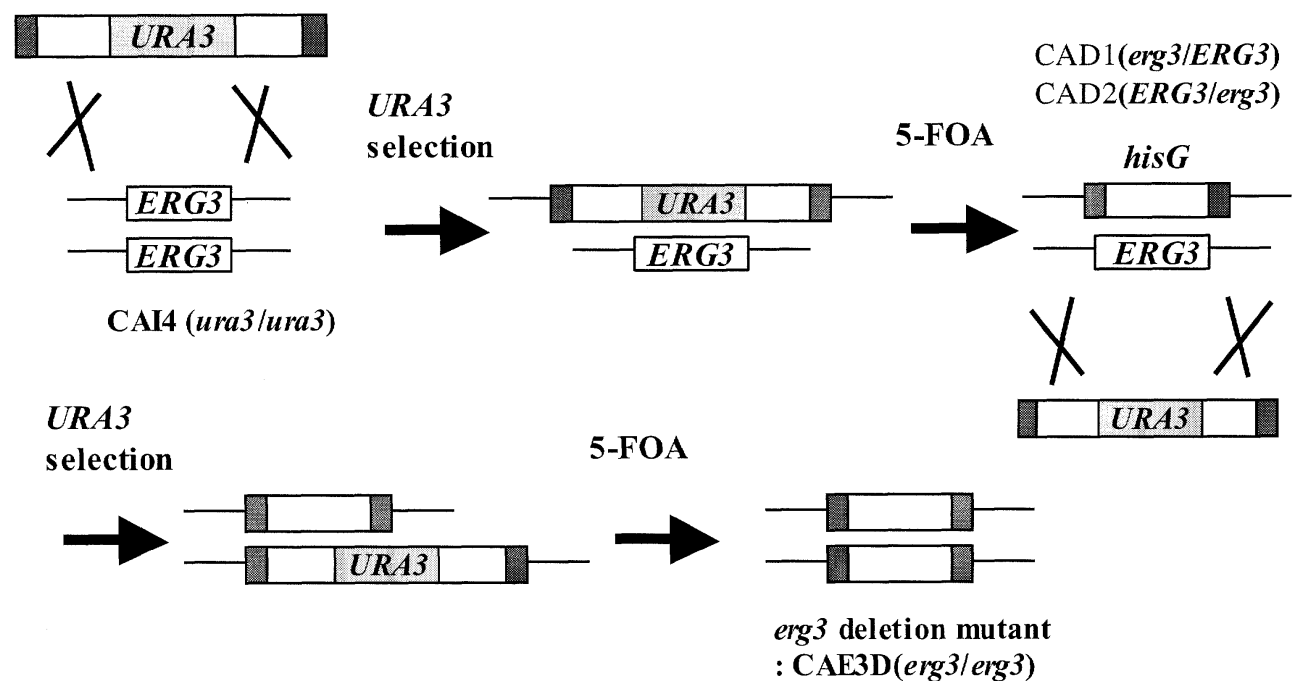

Fig. 3. The methods for gene disruption ${ }^{14)}$.

The erg3 single deletion mutant (CAD1: erg3/ERG3, CAD2: ERG3/erg3) and double deletion mutant (CAE3D, erg3/erg3) are made from CAI4 strain using URA3-hisG cassette.

株由来の $E R G 11$ 遺伝子, Y132H, I471T それぞれのアミ 八酸変異を誘導する point mutation を有する ERG11 遺 伝子をプラスミド（YEP351G）に結合し，Saccharomyces cerevisiae に導入し, ERG11 遺伝子上流のプロモータを活 性化することにより過剰発現を誘導した。薬剤感受性の 検討には E-test を使用した. その結果, 感受性株由来の $E R G 11$ 遺伝子を導入した株の MIC が $1.5 \mu \mathrm{g} / \mathrm{ml}$ であっ たのに対して, Y $132 \mathrm{H}$ 変異を有する場合は $16 \mu \mathrm{g} / \mathrm{m} l$, $\mathrm{I} 471 \mathrm{~T}$ 変異を有する場合は $6 \mu \mathrm{g} / \mathrm{m} l$, 両方の変異を有す る場合は $256 \mu \mathrm{g} / \mathrm{m} l$ 以上であり，それぞれのアミノ酸変 異が耐性に関わり, さらに二つのアミノ酸変異が加わる ことで相乗的な効果を示すことが明らかとなった ${ }^{9}$.

近年，C. glabrata が高率に耐性を獲得することが報告 されているが, その一つのメカニズムとして, C. albicans は, diploid cell であり, 両方の対立遺伝子上に変異が起 こることが耐性獲得のために重要であるが, C. glabrata は haploid cell であり，一つの遺伝子上の変異が，直接 表現系として現れることが考えられている10). 私達の $C$. albicansに方けるERG11 遺伝子の置換実験は，それらの 仮説を支持していると考えられる.

3 ) 薬剂排出ポンプの過㮃発現による細胞内薬剤の減少

薬剤排出ポンプにより細胞外へ薬剤がくみ出され, 細 胞内薬剤濃度が低下することによっておこる耐性機序で ある. 排出ポンプには, ABC transporter と Major facillitator といわれる 2 種類のポンプがあるが, ABC transporter は, ATP を加水分解し, エネルギーとして薬剂を 排出するポンプで, C. albicans では Cdr1p, Cdr2p,C glabrata では CgCdr1p, Pdhlp, C.dubiliniensis では CdCdr1p が報告されている.一方, Major facilitator (MF) transporter は，プロトンの流入と共役して薬剤を排出するポ ンプであり，C. albicans では FLCZ に基質特異的な
CaMdrp やアゾール系抗真菌薬の排出には関係がない とされる Flu1p が報告されている.

新見らは，C. albicans の CDR1 遺伝子を 7 つの主な $\mathrm{ABC}$ transporter 遺伝子が欠損する $S$. cerevisiae にて発現 させ，その役割を検討した，その結果， $C D R 1$ 遺伝子発現 株は，その親株と比較し FLCZ や $\mathrm{KCZ，itraconazole}$ （ITCZ）に対する感受性を 48 倍，31 倍以上，250 倍以上 に低下させた，さらに $C D R 1$ 遺伝子は，他の薬剤や基質 の細胞外排出にも関わっていることが報告されている11).

\section{4 ) 細胞膜の構成成分であるエルゴステロールの合成経} 路における変化

$E R G 3$ 遺伝子にコードされる $\triangle 5,6$ desaturase の活性 が低下し, 細胞膜の構成成分が変化することによる耐性 化機序である.

ERG3 の変異による耐性機序に関して, S. cerevisiae で は, 肯定的な報告がされているが12)，C． glabrata では否 定的な報告もみられる ${ }^{13)}$.

私達は分子生物学的手法を用いC. albicans の ERG3 遺 伝子欠損株を作成し，その薬剤感受性およびステロール 成分を分析した．方法として，はじめに diploid cell で ある C. albicans の ERG3 対立遺伝子の一つを URA3-hisG cassette で置換し，その後 5-FOA プレート上で, URA3 遺伝子を取りのぞいた後に，もう一方の対立遺伝子を再 び同じ cassette で置換して ERG3 遺伝子欠損株を作成し た（Fig. 3).そのアゾール感受性を検討した結果，親株 (CAI4) や一つの対立遺伝子だけを欠損した株（へテロ 接合体 : CAD1; erg3/ERG3, CAD2; ERG3/erg3) の FLCZ に対する MICがそれぞれ $0.5 \mu \mathrm{g} / \mathrm{ml}$ であったが，二つの 対立遺伝子を欠損した株（ホモ接合体 : CAE3D；erg3/ erg3）の MIC は $1024 \mu \mathrm{g} / \mathrm{m} l$ であり，アゾール高度耐性 へと変化していた. それらの細胞膜のステロール成分を 


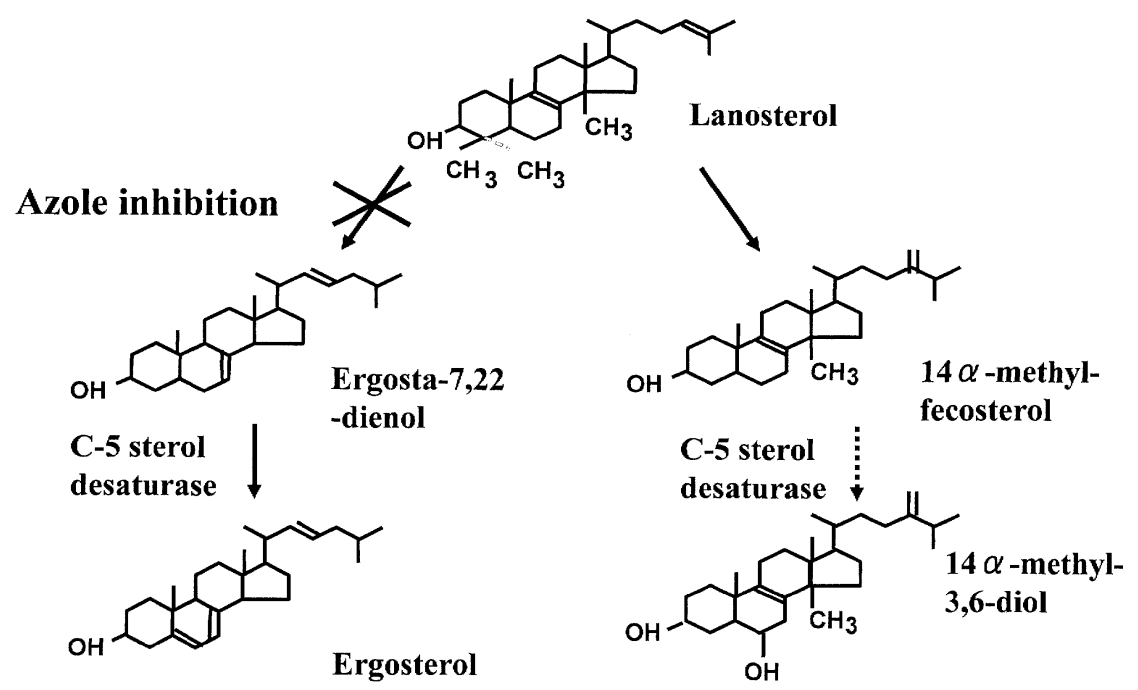

Fig. 4. The toxic effects of the diol in $S$. cerevisiae are eliminated by a mutation in ERG3.

Structures included are lanosterol, the substrate of sterol $14 \alpha$-demethylase in the yeast; ergosta-7,22-dienol, a substrate for sterol, delta 5,6 desaturase; ergosterol, the end-product of the pathway and from azole treated cells, $14 \alpha$-methylfecosterol and $14 \alpha$-methylergosta8,24 (28)-dien-3 $\beta, 6 \alpha$-diol ${ }^{12)}$.

Table 1. Combination of resistance mechanism and stepwise increase of azole resistance ${ }^{15)}$.

\begin{tabular}{|c|c|c|c|c|c|}
\hline \multirow{2}{*}{$\begin{array}{c}\text { Patient } \\
\text { No. }\end{array}$} & \multirow{2}{*}{ isolates } & \multicolumn{3}{|c|}{$\operatorname{MIC}(\mu \mathrm{g} / \mathrm{m} l)$} & \multirow{2}{*}{ Resistance mechanism linked to MIC increase } \\
\hline & & FLCZ & $\mathrm{KCZ}$ & ITCZ & \\
\hline \multirow{3}{*}{ I } & $\mathrm{C} 23$ & 1 & 1 & 1 & S405F mutation on one ERG11 allele \\
\hline & C39 & 32 & 8 & 2 & S405F mutation on both ERG11 alleles \\
\hline & & & & & Increase of mRNA for $C D R 1$ and $C D R 2$ \\
\hline \multirow{4}{*}{ II } & $\mathrm{C} 33$ & 1 & 1 & 1 & \\
\hline & $\mathrm{C} 34$ & 8 & 1 & 2 & S405F mutation on both ERG11 alleles \\
\hline & $\mathrm{C} 82$ & 128 & 32 & 32 & Increase of mRNA for $C D R 1$ and $C D R 2$ \\
\hline & $\mathrm{C} 26$ & 512 & 256 & 64 & Y132H mutation on both ERG11 alleles \\
\hline \multirow{4}{*}{ IV } & $\mathrm{C} 27$ & 1 & 1 & 1 & \\
\hline & $\mathrm{C} 37$ & 8 & 2 & 2 & G464S and R467K mutations on both ERG11 alleles \\
\hline & $\mathrm{C} 40$ & 128 & 128 & 32 & $\mathrm{Y} 132 \mathrm{H}$ mutation on both $E R G 11$ alleles \\
\hline & & & & & Increase of mRNA for $M D R I$ and $C D R 2$ \\
\hline \multirow{3}{*}{$\mathrm{V}$} & $\mathrm{C} 43$ & 1 & 1 & 1 & G129A mutation on one ERG11 allele \\
\hline & C56 & 512 & 256 & 64 & G129A and G464S mutation on both ERG11 alleles \\
\hline & & & & & Increase of mRNA for $C D R 1$ and $C D R 2$ \\
\hline
\end{tabular}

分析した結果, $E R G 3$ 欠損株 (CAE3D) はエルゴステロー ルを欠損し，代わりに，Ergosta-7，22-dien-3beta-ol が生 成されていた，さらに，各株を FLCZ とともに培養する と感受性株には 14-methyl-ergosta-8,24 (28)-dien-3,6-diol が蓄積していたが, $E R G 3$ 遺伝子久損株（CAE3D）では diol の蓄積はみられなかつた ${ }^{14)}$.

$E R G 3$ 遺伝子欠損株ではエルゴステロールが生成され る課程において，アゾールの添加により，Fig. 4 の右の 経路に進むために，その最終産物として diol が生成され る.この diolの蓄積は細胞の発育を阻害し, S. cerevisiae における抗真菌活性の機序と考えられている. $\triangle 5,6$ desaturase をコードする ERG3 遺伝子の欠損により，そ の diol が蓄積しないことがその耐性のメカニズムと考 えられている12).
5 ）複数の耐性機序の関与

さらに高度耐性にはこれらの複数の耐性機序が関与す ることが報告されている.

Sanglard らは, 同一患者より分離され, 段階的にアゾー ル耐性を獲得した C. albicans の而性機序を検討している. その結果, 患者 I では, 元々存在していた ERG11 の $\mathrm{S} 405 \mathrm{~F}$ mutation が両対立遺伝子上におこり,さらに $C D R$ ポン プの活性が加わり耐性を獲得していた. 患者 II では, $E R G 11$ 遺伝子の $\mathrm{S} 405 \mathrm{~F}$ mutation にポンプ遺伝子の活性 化が加わり,さらに $E R G 11$ 遺伝子上で $\mathrm{Y} 132 \mathrm{H}$ 変異がお こっていた. (Table.1) ${ }^{15)}$. Perea らの検討では, HIV 患 者の口腔由来の FLCZ 耐性 C. albicans の耐性機序とし て，ポンプ遺伝子の過剩発現が関与しているものが $85 \%$, $E R G 11$ 遺伝子の mutation が $65 \%, E R G 11$ 遺伝子の過剩 発現が $35 \%$ であり, 複数の機序が関与して高度耐性を獲 
得するものが $75 \%$ あ゙あっと報告されている16)。

\section{6 ）耐性真菌に対する対策}

今後の耐性真菌に対する対策としては, 新しい作用機 序を有する 1,3 - $\beta$-D-glucan 阻害薬や新規トリアゾール 系抗真菌薬（voriconazole, posaconazole, CS758) などの 抗真菌薬, アムホテリシン B の脂質製剂, さらにそれら と従来の抗真菌薬との併用療法, または顆粒球刺激因子 (G-CSF) やマクロファージ刺激因子 (M-CSF), インター フェロンなどの免疫賦活療法の併用などが期待される17)。

\section{おわりに}

近年は，さらなる新たな耐性機序の探索が盛んに行わ れているが，その研究の方法として DNA マイクロアレ イを使用した関連遺伝子の検出は有用な研究法と考えら れる18,19). また病原真菌のゲノム解析により新しい薬剤 耐性遺伝子やその治療法が発見される可能性があり，期 待されている.これらの情報を基にしたゲノム創薬はま だ始まったばかりの状況であるが, さらなるデー夕の蓄 積によりその実現が大いに期待される.

将来的な展望としては, 新しい抗真菌薬の開発や耐性 機序の研究はもとより, 臨床効果を反映するような薬剤 感受性検査の開発, さらに現在 MRSA やVREなどの 一般細菌の耐性菌蔓延から学ぶべき抗真菌薬の適正使用 も重要な課題になってくるものと考えられる.

\section{Reference}

1) Revanker SG, Sanche SE, Dib OP, Cacers M, Patterson FT: Effect of highly active antiretroviral therapy on recurrent oropharyngeal candidiasis in HIV-infected patients. AIDS 12:2511-2513, 1998.

2) Martins $\mathrm{MD}$, Lozano-Chiu M, Rex JH: Declining rates of oropharyngeal candidiasis and carriage of Candida albicans associated with trends toward reduced rate of carriage of fluconazole-resistant $C$. albicans in human immunodeficiency virus-infected patients. Clin Infect Dis 27 : 1291-1294, 1998.

3) Sanglard D, Odds FC: Resistance of Candida species to antifungal agents: molecular mechanisms and clinical consequences. Lancet Infect Dis 2:73-85, 2002.

4) Marichal P, Koymans L, Willemsens S, Bellens D, Verhasselt P, Luyten W, Borgers M, Ramaekers FCS, Odds FC, Bossche HV: Contribution of mutations in the cytochrome P450 $14 \alpha$-demethylase (Erg11p, Cyp51p) to azole resistance in Candida albicans. Microbiology $145:$ :2701-2713, 1999.

5) Kelly SL, Lamb DC, Kelly DE: Y $132 \mathrm{H}$ substitution in Candida albicans sterol 14 alpha-demethylase confers fluconazole resistance by preventing binding to haem. FEMS Microbiol Lett 180:171-175, 1999.

6) Albertson GD, Niimi M, Cannon RD, Jenkinson HF: Multiple efflux mechanisms are involved in Candida albicans fluconazole resistance. Antimicrob Agents Chemother $40:$ 2835-2841, 1996.

7) Miyazaki Y, Geber A, Miyazaki H, Falconer D, Parkinson T, Hitchcock C, Grimberg B, Nyswaner K, Bennett JE:
Cloning, sequencing, expression and allelic sequence diversity of ERG3 (C-5 sterol desaturase gene) in Candida albicans. Gene 236:43-51, 1999.

8) Lai MH, Kirsh DR: Nucleotide sequence of cytochrome P450 L1A1 (lanosterol 14 alphademethylase) from Candida albicans. Nucleic Acids Res $17:$ 804, 1989.

9) Kakeya H, Miyazaki Y, Miyazaki H, Nyswaner K, Grimberg B, Bennett JE: Genetic analysis of azole resistance in the Darlington strain of Candida albicans. Antimicrob Agents Chemother 44:2985-2990, 2000.

10) Lupetti A, Danesi R, Campa M, Tacca MD, Kelley S: Molecular basis of resistance to azole antifungals. Trends Molecul Med 8: 76-81, 2002.

11) Nakamura $K$, Niimi $M$, Niimi $K$, et al.: Functional expression of Candida albicans drug efflux pump Cdr $1 \mathrm{p}$ in Saccharomyces cerevisiae strain deficient in membrane transporters. Antimicrob agents Chemother $45: 3366$ 3374, 2002

12) Kelly SL, Lamb DC, Kelly DE, Manning NJ, Loeffer J, Herbart H, Schumacher U, Einsele H: Resistance to fluconazole and cross-resistance to amphotericin B in Candida albicans from AIDS patietnts caused by defective sterol $\triangle^{5,6}$-desaturation. FEBS Letters $400: 80$-82, 1997.

13) Geber A, Hichcock CA, Awartz JE, Pullen FS, Marsden KE, Kwon-Chung KJ, Bennett JE: Deletion of Candida glabrata ERG3 and ERG11 genes: Effect on cell viability, cell growth, sterol composition, antifungal susceptibility. Antimicrob Agents Chemother 39:2708-2717, 1995.

14) Miyazaki $T$, Miyazaki $Y$, Kakeya $H$, Yanagihara $K$, Hirakata Y, Tomono K, Tashiro T, Kohno S: Abstracts to the 42 st Interscience Conference on Antimicrobial Agents and Chemotherapy, Abstract M-197 Sandiego, CA, 2002.

15) Sanglard D, Ischer F, Koymans L, Bille J: Amino acid substitutions in cytochrome P-450 lanosterol $14 \alpha$ demethylase (CYP51A1) from azole-resistant Candida albicans clinical isolates contribute to resistance to azole antifungal agents. Antimicrob Agents Chemother 32 : 241-253, 1998.

16) Perea S, López-Ribot JL, Kirkpatrick WR, McAtee RK, Santillán RA, Martínez M, Calabrese D, Sanglard D. Patterson TF: Prevalence of Molecular Mechanisms of Resistance to Azole Antifungal Agents in Candida albicans Strains Displaying High-Level Fluconazole Resistance Isolated from Human Immunodeficiency Virus-Infected Patients. Antimicrob Agents Chemother $45:$ 2676-2682, 2001.

17) Canuto MM, Rodero FG: Antifungal drug resistance to azoles and polyenes. Lancet Infect Dis $2: 550-563,2002$.

18) Marianne D. De Backer, Tatiana Ilyina, Xiao-Jun Ma, Sandy Vandoninck, Walter H.M.L. Luyten, and Hugo Vanden Bossche: Genomic Profiling of the Response of Candida albicans to Itraconazole Treatment Using a DNA Microarray. Antimicrob. Agents Chemother 45:16601670, 2001.

19) Marton MJ, Derisi JD, Bennett HA, Iyer VR, Meyer MR, Roberts CJ, Stoughton R, Buchard J, Slade D, Dai H, Bassett Jr. DE, Hartwell LH, Brown PO, Friend SH: Drug target validation and identification of secondary target effects using DNA microarrays. Nat Med $4: 1293-1301,1998$ 


\title{
Azole Resistance in Candida Spp.
}

\author{
Hiroshi Kakeya, Taiga Miyazaki, Yoshitsugu Miyazaki, Shigeru Kohno \\ Division of Molecular and Clinical Microbiology, Department of Molecular Microbiology \\ and Immunology, Nagasaki University Graduate School of Biomedical Sciences \\ 1-7-1 Sakamoto, Nagasaki 852-8501, Japan
}

The emergence of azole-resistant Candida spp. is a significant problem after long-term treatment of recurrent oropharyngeal candidiasis in HIV-infected patients. Several mechanisms can cause this resistance.

An important mechanism of azole resistance is reduced intracellular accumulation of the drug. Among the multidrug efflux transporters, ABC transporters and the major facilitator superfamily are reported to cause the resistance.

Erg $11 \mathrm{p}$, sterol $\mathrm{C} 14 \alpha$-demethylase, is a target of azole derivatives. It was reported that ERG11 overexpression had only a modest effect on the development of azole resistance. However, mutations in the ERG11 gene can cause the resistance, probably by reducing binding of azole to the target enzyme. We sequenced the ERG11 gene in a high-level azole resistant $C$. albicans strain, Darlington, and found that two amino acid substitutions, Y132H and I471T, had been encoded in the Darlington ERG11 gene. To assess the significance of these substitutions, we replaced one of the two copies of ERG11 gene in an azole-susceptible strain of $C$. albicans with a copy of the Darlington ERG11 and this resulted in a modest increase in azole resistance. Furthermore, to estimate the effect of Y132H and I471T individually, ERG11 genes with either or both mutations were expressed in S. cerevisiae. The I471T substitution, not previously described, conferred azole resistance when overexpressed alone and increased this resistance when added to the $\mathrm{Y} 132 \mathrm{H}$ substitution.

Alterations in the sterol biosynthetic pathway are another resistance mechanism. Inhibition of $14 \alpha-$ demethylase by azole results not only in ergosterol depletion but also in accumulation of methylated sterol $14 \alpha$-methylergosta-8, 22 (28)-dien-3 $\beta, 6 \alpha$-diol. We deleted the ERG3 gene, which encodes a sterol 5, 6-desaturase, in C. albicans, and the deletion resulted in reduced susceptibility of the mutant to azoles. Sterol analysis revealed that erg 3 mutant lost both ergosterol and diol when cultured with fluconazole. 